\title{
ARTICLE
}

\section{Legal Due to Local Distribution Towards Land Registration Rights in Ogan Komering Ulu District}

OPEN ACCESS

Citation: Agustina, E. (2021). Legal Due to Local Distribution Towards Land Registration Rights in Ogan Komering Ulu District. Jurnal Bina Praja. 13(1), 125-134

Received: January 30, 2021

Accepted: February 18, 2021

Published: April 30, 2021

(c) The Author(s)

\section{(c) (i) (2) (2)}

This work is licensed under a Creative Commons Attribution-NonCommercialShareAlike 4.0 International License.

\section{Enny Agustina}

College of Law Pertiba Pangkalpinang (STIH Pertiba)

$\checkmark$ ennyagustinadua@yahoo.com

Abstract: The local expansion was a concrete manifestation of local autonomy. In addition, regional expansion is splitting from one region to more than one region to support community welfare. The problems discussed in this study were the consequences of the law of local expansion on the registration of land rights in Ogan Komering Ulu district and solutions to resolve land conflicts due to the expansion of the area. This study uses a normative juridical approach where the literature used is regulations and books. In conclusions, the legal consequences of the division of Ogan Komering Ulu District on the implementation of land registration indicate a change in the work area and authority for making land deeds by the Land Deed Making Officials and changes in the work area and authority in carrying out the duties and obligations of registering land at the Land Office of Ogan Komering Ulu district. To solve this conflict problem, the Ministry of Home Affairs sometimes must intervene in the dispute resolution process. Conflicts like this can hinder the wheels of government in the regions. Another solution is for the government to immediately finalize the grand design while still paying close attention to historical aspects and customs before many conflicts occur in the regions.

Keywords: Local Expansion, Land Conflict, Land Rights. 


\section{Introduction}

The Unitary State of the Republic of Indonesia, which was based on the 1945 Constitution, was a constitutional state which guarantees and provides protection for the rights of citizens, among others, to obtain, own, and enjoys property rights over land. However, land that was the basic life for humans will face a shift in the pattern of relations between landowners and land because of changes brought about by the development process and social changes. (Sutedi, 2014) Although the relationship between humans and land is natural, experts have always had different opinions about the nature of this relationship, meaning whether humans, as individuals, communities, or the state, can have direct relations with the land. In this case, the direct relationship meant is property right. (Usman, 2011). The Basic Agrarian Law provides regulations regarding property rights, in Articles 20 s.d. Article 27, however, only deals with fundamental matters. Article 56 states that if the law regarding property rights as referred to in Article 50 paragraph (1) has not been established, the provisions of local customary law and other regulations as referred to in Article 20 shall apply if they do not conflict with soul and the provisions of this law (Diamantina, 2010). To ensure certainty of rights and legal certainty over land, the Basic Agrarian Law outlines the need for land registration throughout Indonesia; article 31 of Government Regulation Number 24 of 1997 concerning land registration states that certificates issued are for the benefit of rights holders. The person concerned issues a certificate following the data, physical and juridical data that has been registered in the land certificate.

Local government management will be more effective in implementing the division of authority between the local heads of government. Local deputy heads were based on Legislation and written down (formal juridical). The division of tasks, functions, and power is carried out in the initial stages (planning) of the implementation of local government so that performance that refers to clear rules will be able to increase the effectiveness of the administration of local government (Solihat \& Nugraha, 2016).

The elections have created a working relationship between the Local Heads and Local Deputy Heads (Wijayanti, 2016). This relationship is established simultaneously with each candidate's election to go forward in the elections; each cadre has a Local Deputy head who will carry out the vision and mission made before serving as Local Heads. Local Deputy Heads appointment is only an assistant to the Local Heads in carrying out government tasks. Based on Law No. 23 of 2014 concerning Local Government, Election of Local Leaders and Local Deputy Heads are elected in a package (Sularno, 2006). The lack of synergy between local autonomy and local elections is the gap between expectations and reality and conflicts at the ideological and technical levels. (S, 2020).

The context of the relationship between the Local Heads and Local Deputy Heads, Law No. 23 of 2014 concerning local government, has failed to harmonize the relations between the two, thus disturbing government stability in the regions. Revisions to acts are needed, including those that regulate how local deputy heads should be elected, so as not to create instability in local governments (Guyanie, 2015, p. 37).

Good relations and cohesiveness between the Local Heads and Local Deputy Heads are evident at the time of the nomination, the campaign until the inauguration, and the taking of oaths to celebrate the pair of Local Heads and Local Deputy Heads. There are a good relationship and compactness between the Local Leaders and Deputy Local Leaders, which only lasts a few years or a few months until the compactness slowly disappears. Perspectives position of Local Deputy Heads of the local government system, Local Deputy Heads, or Deputy Heads of the Institute should be removed. The parts and functions of the Local Deputy Heads must be replaced with the secretary (Haruni, 2013).

The relationship between the Local Heads and Local Deputy Heads often creates conflicts to disharmony. Reduced harmony between the Local Heads and Local Deputy Heads occurs in many regions in Indonesia. Some things that became the conclusion of a joint venture between the Regent and Deputy Regent were: Internal aspects of the party that only focused on one candidate as regent. The external factor of the party is 
another bid to form a more likely coalition, and one of the district head candidates has a reasonably wide network. One of the political steps of the candidate for district head was very rational, so they decided not to form a coalition (Taqwa, 2017).

Because of a powerful image, making a Local Heads is only a means of popularizing himself. Deputy Local Leaders did not hesitate to challenge their Local Heads in the following Local Elections when it was popular. The disharmony and disunity between the Local Heads and Local Deputy Heads in the province, district/city, has occurred a lot before and after the elections (Agustina, 2019b). The Local Head's pair split naturally causes the community service to be suboptimal and disharmony relationships that affect the bureaucracy. Some bureaucracies are loyal to the Local Heads, and there are also loyal ones to his Deputy. Besides, there can be differences of opinion between the Local Heads and his Deputy in every policy decision. This difference of opinion raises a long time to make a policy decision. The disharmony problem between the Local Heads and his Deputy results in sub-optimal government services, and the people are disadvantaged.

Disharmony between the Local Heads and Local Deputy Heads then worsens leadership pattern in carrying out governance in the region. Harmonization between the Local Leaders and Deputy Local Leaders is essential to the government's running, especially for the community's benefit. The community will certainly feel its impact on the disrupted government process due to the lack of cohesiveness of the Local Heads and Local Deputy Heads in his area. Relationships between Local Heads and Local Deputy Heads are not harmonious, so the process of governance and local development will not run well, nor will it improve the welfare of the community (Agustina, 2019a).

Whereas according to the law, Local Deputy Heads has exact duties, authorities, obligations, and functions, namely oversight, consultative, coordinating, and executive functions. Although this does not fully indicate that power-sharing between the Local Heads and his Deputy is ideal. Corrections are still needed relating to the strict division of authority between the Local Leaders and his Deputy, not to cause political tension.

But it is also not entirely true. It was concluded that the fracture of the relationship between the two is due to the struggle for authority. The most prominent issue at the root of the problem is the mechanism for filling the position of Local Deputy Heads. With the people's direct election mechanism, some Deputy Local Leaders have more political power than their Local Leaders. That is, the Local Deputy Heads may only be used as a vote gatherer in some cases. In other cases, the Local Deputy Heads were only used as a cash machine and "ATM" during the campaign (Fleiner \& Fleiner, 2009).

On the other hand, the direct election of Local Heads or direct democracy provides direct political education to control the local government. Fleiner \& Fleiner believe that with direct democracy, the people can exercise maximum control over the local budget. While Fleiner states:

"The exercise of political rights through direct democracy enables the citizens to control the income and expenditure of their municipal authorities. Citizens elect their representatives to the local parliament and the municipal executive. It is at the local level that young politicians have to prove themselves. Municipalities often serve as an experimental field for many political initiatives. It is the arena in which citizens can develop their social and political competence."

Disharmonization of local heads can undoubtedly disrupt the wheels of government, that one of the factors driving the increase and effectiveness of leadership is a harmonious relationship. The large percentage of pairs of Local Heads and Local Deputy Heads conflicts and conflicts that are not harmonious due to:

1. Because the coalition is built only by strengthening political support only on the post-conflict election, the alliance did not build on the main objectives, namely stability. As a result, the strength of the government did not last long.

2. So far, it carries the coalition that has been built out by a combination of two or more political parties, a variety of two different ethnic groups, or a combination of two other religious groups.

3. There is no firmness about the division of authority between the Local Heads and Local Deputy Heads in the Law on Local Government to take power from each other. 
4. Local Heads were overly dominant in decision-making. On the other hand, there is no awareness of the Local Deputy Heads about his position. Both felt the same struggle during the elections, giving rise to the desire to equalize the division of tasks, especially on projects, or equal in decision making on the placement of officials on decolonization, and moving the duties Civil Servants of their respective supporters.

The publication system used was a negative publication system that contains a positive element because it will produce letters of proof of rights which are valid as a strong means of evidence, as stated in article 19 paragraph (2) letter c, article 23 paragraph (2), Article 32 paragraph (2) and Article 38 paragraph (2) UUPA, but not a pure negative publication system

Based on the provisions governing the collection to the presentation of physical data and juridical data required as well as their maintenance and issuance of rights certificates, even though the publication system was negative, the activities concerned were carried out carefully so that the accuracy of the data presented can be accounted for (Usman, 2011). Article 36 paragraph (1) of the Basic Agrarian Law states that the maintenance of land registration data is carried out if there was a change in physical data or juridical data on land registration objects that have been registered. Meanwhile, Article 20 paragraph (2) of the Basic Agrarian Law states that property rights are hereditary, strongest, and most absolute rights that can be owned according to Article 6 of the Basic Agrarian Law. Ownership rights to land as a property right are very important for the State of the Nation and the Indonesian people as an agrarian society developing towards industrial development and others.

Historically it can be said that the peak of land disputes has occurred since the enactment of the 1870 Colonial Agrarian Law known as the Agrarische Wet, where the main source of land conflicts and disputes lies in the disharmony, inconsistency, or inequality that exists in the structure of land ownership and control. (Sumardjono, 2018) It can be said that cases involving disputes in the land sector never subside; even the level of complexity tends to increase according to the problem and quantity and changes in society in the economic, social, and political fields. (BF, 2014) At present, there are many disputes related to land, one of which is the dispute regarding double certificates (Chomzah, 2011).

Double certificates are certificates that correspond to the same plot of land. Accordingly, one land parcel was described with two or more certificates with different data. This was also called an overlapping certificate, either overlapping all the parcels or overlapping part of the land parcels. A double certificate in the land sector is often known as a certificate dispute where this can have legal consequences. The legal result of the overlapping status of land ownership rights causes losses because a double title certificate will cause many losses. After all, the land in a case will be challenging to sell; this is due to the guarantee of legal certainty, both subject and object, which does not yet exist. The selling price of the land will decrease (Guyanie, 2015).

The cause of double/overlapping certificates, among others, is that the registration map has not been formed or is incomplete. It occurs because of the applicant's bad faith, which was carried out with an element of intent, such as showing boundaries that are not their right to obtain personal gain. In this case, the task of the National Land Agency is only to carry out measurements based on the determination of the boundaries indicated by the applicant. Namely, where the location and limitations with the agreement of the neighbors bordering the land, these two things can cause overlapping, whether intentional or unintentional, resulting in a double certificate. The occurrence of division and expansion of areas resulted in territorial boundaries changes (Suhartono, 2015).

The expansion of the District is a concrete manifestation of the existence of Local Autonomy. Besides, regional expansion was a process of solving from one local to more than one local as community welfare. Still, the factors that are often suspected of being the leading cause of the high aspirations for the proposed Local Expansion amidst many negative assessments of the success of this program are the basis for the reason for the expansion. The reasons for expansion are never singular; they often overlap between social, political, and economic reasons. Sub-district division also 
often overlaps ownership of land, parcels, and overlaps of part of the land parcels.

Based on the description, the study's objectives were as follows: (1) the effect of regional expansion on the registration of land rights in the Ogan Komering Ulu district and the solution to resolve land conflicts expansion of the area.

\section{Research Methods}

The approach method used is a normative juridical approach or normative legal research. Normative juridical legal research is an approach method used to determine legal norms contained in statutory regulations. (Soerjono Soekamto dan Sri Mamudji, 2013) All data obtained from the research results will be analyzed using descriptiveanalytical methods. It is research by reviewing and analyzing articles of statutory regulations and also describing how a statutory regulation is implemented if we relate to all the limitations of law with all The strengths and weaknesses of both juridical and non-juridical factors and analyze them based on all the data obtained in implementing positive law concerning the above problems.

The research data sources consisted of primary data and secondary data. Primary data is the source of data obtained not through intermediary media or obtained directly from sources. Primary data can be in opinions, observations, events or activities, and test results. (Soerjono Soekamto dan Sri Mamudji, 2013) Secondary data comes from library research, where the legal material comes from primary legal materials and secondary legal materials. Collecting data in this study requires data from books, literature, and opinions of legal experts related to this research or other sources to support the success and effectiveness of the research.

The data analysis method used in this legal research is qualitative normative. It is said to be normative because this research starts from existing regulations as national positive legal norms. Meanwhile, qualitative means that the data analysis carried out is based on efforts to discover legal principles by examining the contents of statutory regulations and the secondary data obtained. (Soerjono Soekamto dan Sri Mamudji, 2013)

\section{Results and Discussion}

\subsection{The effect of the law of local expansion on the registration of land rights in Ogan Komering Ulu district}

The division of the district/city into several new districts/cities to improve the quality and intensity of services to the community. (Tarigan, 2010) In terms of local development, the new district/city candidates that will be formed need to have a resource base that is balanced from one another. It is necessary to make efforts so that there will be no striking disparities in the future. Furthermore, to expand the territory, a new public space will be created, which is the collective need of all citizens of the new territory. This new public space will affect the activities of a person or society so that they will feel benefited because of their maximum service. (Widjaya, 2011)

Finally, the division of this region aims to improve the welfare of the community, sustainably increase resources, increase the harmony of development between regions and between sectors, strengthen national integration, which can improve the quality of life. (Syaukani, 2010)

Several reasons arise when an area is divided; first, it is related to the control range of an area that is considered too broad, so that the control of an area is considered too broad so that in order to bring policymakers (who are located in the regional government capital) closer to the community, it is deemed necessary to present an institution and government structure. New area. This reason is related to efforts to improve the quality of local government services to the community. Second, to create equitable development since the concentration of activities and (economic) development growth is always in the capital city of regional government and the surrounding area (Idham, 2014)

Government Regulation Number 78 of 2007 is an improvement of Government 
Regulation Number 129 of 2000. Government Regulation Number 129 of 2000 concerning Requirements and Establishment of Expansion Areas requires that the formation of provinces must have at least three district/cities. Another arrangement is that the age limit for an autonomous region can only be re-expanded if it is ten years for the province and seven years for districts/cities. (Bilder, 1989). The Government Regulation is also about the requirements for the formation of the newly created regions. Later, it will also contain a study of the areas to be expanded. In Government Regulation Number 129 of 2000, the study of the newly created regions includes only seven quantitative criteria. So, the Government Regulation Plan (RPP) will consist of 11 quantitative assessments of the division area study (Himim, 2017). Article 6 of Government Regulation Number 78 of 2007 requires 11 quantitative assessments, namely:
a. Population
b. Financial Capability
c. The economic capacity of the community
d. Socio-Culture
e. Social and Political
f. Local Potential
g. Area
h. Defense
i. Security
j. Level of Community Welfare
k. Range of governance returns.

The expansion of a local area carried out by taking part of the adjacent area because of the legal consequences of the Land Deed Making Official has not been clearly and firmly regulated in statutory regulations. The law only regulates the division of a district/city into two or more districts/cities. The legal consequence of the division of the Ogan Komering Ulu district on the implementation of land registration activities is that there is a change in the work area and authority in making land deeds by the Land Deed Making Official as well as changes in the work area and authority in carrying out duties and obligations to perform land registration. Changes in the Land Deed Making Officials and District Land Offices ogan ulu commuting changes in the work area and authority, bearing in mind that the Land Deed Making Official and the Land Office are in the District/City area following the prevailing laws and regulations.

Based on cause and effect, of course, disharmony between the Local Heads is undoubtedly a cause, and there are consequences. In many cases, the elected local heads usually only feel 3-10 months in harmony, then disharmony will follow. Many observers say the factors causing conflict are political maturity, uneven distribution of power, and a thin nationalism state. Apart from being good at politics, political elites must also have political maturity. The political maturity of the political elites, especially in the regions today, is of great concern. After being elected, the Local Heads usually carry out their duties; ideally, local heads should complement each other. When the task is not equal, political maturity will decrease. The head of the region usually regards his deputies only as "Reserves," not his partners. It causes local representatives to be often "not considered" and intend to compete in future elections.

The division of tasks and functions, in the local government law No. 23 of 2014, it is obvious to specify the duties and functions of Local Heads and Local Deputy Heads. At every political moment, the Local Heads often buys this activity, meaning that even the region's deputy head is often not allowed to cut off the inauguration tape. It usually happens near the next election. The Local Heads entered the last year as if "spying" Local Deputy Heads not to use his position to rival the Local Heads-what an unintelligent political situation (Diamantina, 2010).

Impact of this disharmony, many effects will arise from the conflict of Local Heads. The first thing that sacrificed the most is Society. In a campaign, the Local Heads and Local Deputy Heads generally change their "sweet" promises and will be fought together between Local Heads and Local Deputy Heads of the region. Still, because of 
"broken joints," these promises remain memorable. Another thing that will emerge is the ineffectiveness of tasks and functions. Because the local heads have "elbowed" each other and do not trust each other, indeed, the government will no longer be effective. And again, the victims are the people. Back at the heart of the problem is that an initial analysis can be drawn because of the government system, especially the election with a "package" that is not optimal and individual and state of nationalism.

In several government studies, several options had put forward to minimize this disharmony. One of them is the establishment of governance systems.

1. First, local heads are no longer elected as a "package" but instead are chosen individually. The division of tasks is clear, and the local heads are no longer struggling to "spy on" the deputy Local Heads who will compete in the next election. If took this option, the regulations and laws must be changed, improving the system itself.

2. Second, because the local heads are filled with individuals, the local deputy heads are taken from civil servants (PNS). It is because civil servants are career positions and will not wrestle in the political field. Civil servants are also very understanding of governance; this option is very logical. And the essential thing is civil servants (PNS) will not compete with the regional head in the next election, as is the case in many regions. Technically, the deputy head of the region is taken from the civil servants at least with the rank of echelon I B, which can then be appointed as deputy Local Heads on a proposal from the ministry of the interior and approved by the Regional House of Representatives (DPRD).

The disharmony of local heads is very dangerous and has a complex impact, both politically and administratively. Suppose this disharmony cannot be inhibited through the Individual local heads. In that case, it must inhibit by establishing the system so that people are no longer victims of the war between political elites (Azwar, 2016)

\subsection{Settlement Solutions in Overcoming Land Conflicts Due to Local Expansion}

To solve this conflict problem, the Ministry of Home Affairs sometimes has to intervene in the dispute resolution process. Conflicts like this can hinder the wheels of government in the regions. Another solution is for the government to immediately finalize the grand design while still paying close attention to historical aspects and customs. Before, there were many conflicts in the regions. If this is ignored, such as in historical terms customs (Ida Ayu Riani dan M. Pudhjihardjo, 2012).

Any proposals regarding the expansion of regions or establishing a new province district/city and sub-district should genuinely be the commitment of the majority of citizens, not merely an intention at the elite level (Agustina, 2018).

The plan for local expansion that continues to blow in the era of Local Autonomy must be appropriately directed to bring the functions of the Local Government bureaucracy closer to its people. Because without this, the perception that links the discourse of regional expansion is just a euphoria of autonomy which is only related to the logic of power. There are several variables to measure local expansion's feasibility, namely boundaries and population, economic potential, natural resources, and human resources. (Saputra, 2008)

The local government has a very important role in the framework of fostering and supervising village government. (Agustina, the role of community empowerment carried out by village government in the regional autonomy, 2019)

In the Acts of Local Government, which replace acts No. 32 of 2004, declared that the position of Local Deputy Heads, including how the mechanism of filling the place, really experienced a very revolutionary change.

In the draft, Deputy Local Heads is a state echelon level IB for deputy governor, and echelon IIA level for Deputy Regent or Deputy Mayor. However, Local Deputy Heads stopped simultaneously with the Regional Head. It shows that the Local Deputy Heads is not a political office as in the previous law.

Indeed, there was a lot of encouragement, especially from the Regional House of Representatives, which suggested that the Local Deputy Heads was not elected in 
pairs with the Local Heads. Because from the beginning, the position of Deputy Local Heads as a companion to the Local Heads. Ideally, the Deputy Local Heads are elected by the elected Local Heads, not selected in pairs directly

In the Bill, the Governor proposes the Deputy Governor candidate twice the number to the president through the minister. This also applies to candidates for Deputy Regent or Deputy Mayor, presented by the Regent or Mayor to the Minister through the Governor (Suhardin, 2007).

Even in the new draft law, not every region, both provincial and regency or city, has a Deputy Regional Head. For provinces with a population of less than 3 million, there is no Deputy Governor position. Whereas regions with a population of 3 million to 10 million have one deputy governor. For areas with a population of over 10 million, there are two deputy governors.

The draft shows that the Deputy Governor's position is based on each provincial region's needs, which is undoubtedly different. The deputy governor's role is not a political position, which must exist in each region regardless of its urgency.

Likewise, deputy regent or deputy mayor is not owned by a regency or city whose population does not reach 100 thousand inhabitants. But if the population is above 100 million, then there is one deputy regent or deputy mayor (Sudrajat et al., 2018). Do not let the same political legitimacy source cause political existence between the Local Heads and his deputy. Local Heads are elected directly by the people, their representatives are also directly elected by the people, but their authority is different. Local Heads more "exist" and get the stage and wetlands, while their representatives do not get a commensurate ratio.

But do not let appointing the Deputy Local Heads as the elected Local Heads is not objective. It means that standards, indicators, and variables can determine candidates for the Local Heads from among the local bureaucrats. Seeing its implementation during the New Order, it tends to abandon the principles of law and justice. In the New Order era, determining Local Heads and their deputies depended on the choice of the center, even not following the aspirations of the local community. At the beginning of the reform, the Local Heads and his deputy were in the shadow of the Regional House of Representatives (DPRD) power because it determines whether or not a candidate becomes the Local Heads.

Most of the above tasks are still the same as those of the Deputy Local Heads regulated in Law No. 23 of 2014 (Abdullah, 2007), So it needs to be reviewed whether re-identification is necessary related to these tasks so that they are relevant to the context of the idea of changing the Law on Local Government.

In addition to carrying out the above tasks, the Deputy Local Heads carry out other governmental duties and obligations granted by the Local Leaders determined by the Local Leaders decision In addition to carrying out the above tasks, the Deputy Local Heads carry out other governmental duties and obligations granted by the Local Leaders determined by the Local Leaders decision is responsible to the Local Leaders (Bilder, 1989).

The division of tasks and authority between the Local Heads and his Deputy must be firm and clear to avoid dualism and overlap. With the division, as stated in the RUU above, it means that the Deputy Local Heads becomes the Local Heads' assistant and is responsible to the Local Heads.

Currently, changes to the law to improve the legal politics of the relationship between the center and the regions are in sight, including materially governing the position, authority, and mechanism of filling the part of Deputy Local Heads, which is an ideal decentralized system. Moh. Mahfud, M. D., changes that constitute a state demand must also be responded to in arranging local government if the changes do not change the legal. Political foundations outlined in the constitution, namely the traditional politics of the unitary state and the politics of broad autonomous law with a decentralized and deconcentrated system that pays attention to the original rights of the region (M. D., 2010).

That was the Indonesian people's dream with the vast territory and diversity of its 
population to build a harmonious unitary Republic of Indonesia both vertically and horizontally.

Article 30 of Law no. 22 of 1999 concerning the Local Government states that "A Local Heads leads each region as the head of the executive assisted by a Deputy Local Heads." So, in Law no. 22 of 1999 concerning Local Government, Deputy Local Heads existence has been regulated. Where local leaders and Deputy Local Heads are indirectly elected, in this case, they are elected by the Regional House of Representatives (DPRD).

Article 24 paragraph (1) and (3) Law no. 32/2004 states that: "a Local Heads of government leads each region called the Local Heads, who are assisted by one deputy regional head. Furthermore, the deputy Local Leaders can be divided into provinces called deputy governors, districts called deputy regents and for cities called deputy mayors. The said Local Heads and Deputy Local Heads are directly elected as a pair by the people in the region concerned".

So, Deputy Local Heads in Law No. 32 of 2004 concerning Local Heads, which states that each region is led by a Local Heads and assisted by a Deputy Local Heads. Local Heads are representatives of the central government in the areas, and public officials are elected based on political recruitment or direct election models and carry out their mandate.

In the discussion of regulating the authority of Local Heads and Deputy Local Heads, we will look at the laws and regulations that have been in effect and have been positive in Indonesia.

As the spearhead of service to the community, the Regent carried out the duties and responsibilities that must be carried out in carrying out government, service, and development tasks. In addition to carrying out general duties, the Regent also carries out the governmental authority delegated by the government above him to handle some autonomous affairs regions, which include aspects of licensing, recommendations, coordination, guidance, supervision, facilitation, determination, administration, other delegated powers. (Agustina, The Implementation of Law Number 6 the Year 2014 on Village Government., 2019). The delegation of some of this authority is carried out based on the criteria of externalities and efficiency. Thus, the district government has a very influential task and role for the village, for this reason, the district government of Ogan Komering Ulu seeks to resolve the conflict over regional expansion to create cooperation between villages in building a better area, while the efforts that are being tried are as follows:

The Regional Governance and Autonomy Section at the Regional Secretariat of OKU Regency resolve Village boundary disputes, namely by knowing how to establish, affirm and ratify Village boundaries. The settlement of disputes over Village boundaries between villages in different Subdistricts in one District/City is resolved by deliberation or consensus facilitated by the Regent or Mayor and included in the minutes. Village boundary disputes must be settled in a maximum of six months. Proposals regarding the expansion of districts/cities and new sub-districts should truly be the commitment of the majority of citizens, not merely an intention at the elite level. And directed to get closer to the function of local government bureaucratic services to the people.

\section{Conclusion}

Based on the result and discussion, it can be concluded that:

1. The legal consequence of the division of the Ogan Komering Ulu district on the implementation of land registration activities in the Ogan Komering Ulu district is a change in the work area and authority in making land deeds by the Land Titles Registrar (PPAT) and changes in the work area and authority in carrying out duties and obligations to register land in the Land Office of Ogan Komering Ulu district in terms of land registration. Changes to the work area and authority of the PPAT and the Land Office of the Ogan Komering Ulu District, considering that the duties and authorities of the Land Titles Registrar (PPAT) and the Land Office are in the District/City area following the applicable laws and regulations. 
2. To solve this conflict problem, the Ministry of Home Affairs sometimes has to intervene in the dispute resolution process. Conflicts like this can hinder the wheels of government in the regions. Another solution is for the government to immediately finalize the grand design while still paying close attention to historical aspects and customs before many conflicts occur in the regions. Suppose this is ignored, such as in historical terms, customs. Any proposals regarding the expansion of areas or establishing a new province district/city and sub-district should genuinely be the commitment of the majority of the population, not merely an intention at the elite level. The plan for local expansion that continues to blow in the era of Local Autonomy must be properly directed to bring the functions of the Local Government bureaucracy closer to its people. Without this, the perception that links the discourse of local expansion is just a euphoria of autonomy related to the logic of power. At least there are several variables to measure the feasibility of local expansion, namely boundaries and population, economic potential, natural resources, and human resources.

\section{References}

Agustina, E. (2018). Legal malfunctions and effort in reconstucting the legal system service: A state administrative law perspective. Jurnal Dinamika Hukum, 357-364.

Agustina, E. (2019). The Implementation of Law Number 6 Year 2014 on Village Government. International Journal of Innovation, 104-114. https://scholar.google.com/ scholar?oi=bibs\&cluster $=9440639525765356552 \&$ btnI $=1 \&$ hl=en

Agustina, E. (2019). The role of community empowerment carried out by village government in the regional autonomy. Unifikasi: jurnal ilmu Hukum, 34-39. https://core.ac.uk/download/pdf/295436564.pdf

Aminah, S. (2020). The Evaluation of Regional Head Election: Developing Synergy of Regional Autonomy and Regional Head Election. Jurnal Bina Praja: Journal of Home Affairs Governance, 12(2), 137-151. https://doi.org/10.21787/ibp.12.2020.137-151

BF, S. (2014). Evolusi kebijakan pertanahan dalam hukum tanah Indonesia. Jakarta: PT Toko Gunung Agung TBK.

Bilder, R. B. (1989). The role of states and cities in foreign relations. American journal of internasional law, 821-831. https://doi.org/10.2307/2203371

Chomzah, A. A. (2011). Hukum Pertanahan Seri Hukum Pertanahan I- Pemberian Hak Atas Tanah Negara dan Seri Hukum Pertanahan II- Sertifikat dan permasalahannya. Jakarta: Prestasi Pustaka.

Diamantina, A. (2010). Pengawasan atas penyelenggaraan pemerintah daerah untuk mewujudkan pemerintah daerah yang efektif dan efisien. Masalah- Masalah Hukum, 36-43. https://ejournal.undip. ac.id/index.php/mmh/article/view/11958

Guyanie, G. E. (2015). Politik Hukum Pengaturan Jabatan Wakil Kepala Daerah dalam Sistem Desentralisasi. In Right: Jurnal Agama dan Hak Asasi Manusia, 19-40. http://ejournal.uin-suka.ac.id/syariah/inright/ article/view/1288

Himim, R. (2017). Dasar hukum Pembentukan Pemekaran Wilayah dalam Sistem Pemerintah Otonomi Daerah. Bandung: Eresco.

Ida Ayu Riani dan M. Pudhjihardjo. (2012). Analisis dampak pemekaran wilayah terhadap pendapatan per kapita. Jurnal bumi lestari, 137-148. https://ojs.unud.ac.id/index.php/blje/article/view/1544

Idham. (2014). Konsoliasi tanah perkotaan dalam perspektif otonomi daerah. Bandung: alumni.

Saputra, A. (2008). pemekaran daerah dan implikasinya terhadap pembangunan. Jurnal administrasi publik, 69-82. https://media.neliti.com/media/publications/73199-ID-pemekaran-daerah-dan-implikasinyapada-p.pdf

Suhartono. (2015). Ketimpangan dan Pembangunan Ekonomi Kabupaten Kota di Daerah Hasil Pemekaran. Jurnal ekonomi dan Kebijakan Publik, 33-34. http://jurnal.dpr.go.id/index.php/ekp/article/view/154

Sumardjono, M. S. (2018). Mediasi Sengketa Tanah (Potensi Penerapan Alternatif Penyeleaian di bidang Pertanahan. Jakarta: Kompas.

Sutedi, A. (2014). Pealihan Hak Atas Tanah dan Pendaftarannya. Jakarta: Sinar Grafika.

Soekanto, Soerjono dan Sri Mamudji, (2013). Penelitian Hukum Normatif: Suatu Tinjauan Singkat, Jakarta: Raja Grafindo Persada

Syaukani. (2010). Otonomi Daerah Dalam Negara Kesatuan. Yogyakarta: Pustaka Pelajar.

Tarigan, A. (2010). Dampak Pemekaran Wilayah. Jakarta: Perencanaan Pembangunan.

Taqwa, Z. (2017). Pecah Kongsi Bupati dan Wakil Bupati Incumbent dalam Pemilihan Kepala Daerah di Sidoarjo (Studi Rational Choice Pemilihan Kepala Daerah di Kabupaten Sidoarjo) [Universitas Airlangga]. http://repository.unair.ac.id/id/eprint/67854

Wijayanti, S. N. (2016). Hubungan Antara Pusat dan Daerah dalam Negara Kesatuan Republik Indonesia Berdasarkan Undang-Undang Nomor 23 Tahun 2014. Jurnal Media Hukum, 23(2), 186-199. https:// doi.org/10.18196/imh.2016.0079.186-199

Usman, A. H. (2011). Politik Hukum Agraria Indonesia. Palembang: Tunas Gemilang Press.

Widjaya, H. (2011). Otonomi Daerah dan Daerah Otonom. Jakarta: Rajawali Press. 